\title{
THE EFFECT OF RENEWABLE ENERGY SOURCES ON THE GLOBAL POWER INDUSTRY
}

\section{T.Lanshina}

The global power market is undergoing an important transformation. Successful development of technologies of renewable energy sources (RES) and even a complete switchover of individual countries to those technologies is no longer a technical or economic problem. Some cities, regions and even countries have already set a goal to switch over completely or partially to RES. In the near future, in the power industry the existing trends are expected to consolidate: prices on RES technologies are going to depreciate and the share of RES in the power sector is bound to rise. In Russia, no radical changes on the power market are expected so far: in accordance with the officially approved plan only 6 GW of new REC power stations which are going to ensure $4.5 \%$ of the country's entire power consumption will be built in Russia by 2024.

The global power market is undergoing an important transformation. After the accident at the Fakusima-1 nuclear power plant, public pressure on the nuclear power industry has grown, particularly, in Europe where a lot of countries intend to shut gradually nuclear power plants. Despite a recent drop in prices on some fossil fuel, renewable energy keeps developing actively and sets new records. For the first time in the past 25 years, in 2015 greenhouse gas emissions remained virtually at the level of the previous year.

In the past few years, a number of international agencies, investment banks and other institutions issued reports stating that in some parts of the world RES technologies were getting more and more competitive as compared to the power industry based on fossil fuel and nuclear power.

A key indicator of RES economic efficiency is a levelized cost of energy, that is, average imputed cost of power generation during the entire period of operation of a power plant, including capital and operating costs and expenditures on fuel (if any). According to the existing international practice, if the levelized cost of RES-generated power is not higher than the value of the traditional power generation indicator and existing tariffs a renewable energy source is regarded competitive. It is to be noted that RES competitiveness depends highly on the region of operation.

One of the most reliable sources in terms of evaluation of RES competitiveness is the Lizard, a US investment bank which has carried out such research on an annual basis since 2009. According to its latest research ${ }^{1}$ published in November 2015, in the 2009-2015 period the levelized cost of solar and wind generated power fell by $82 \%$ and $61 \%$, respectively. The credit for that goes to scientific and technological progress, that is, innovations and commercialization of research outputs. As a result, in 2015 the levelized cost of $1 \mathrm{MWh}$ of solar generated power on a commercial scale (that is, by power companies and not households participating in distributed generation) amounted to $\$ 50-\$ 70$; as regards wind-generated power that indicator was equal to

1 Lazard. Lazard's Levelized Cost of Energy Analysis - Version 9.0, 2015. https://www.lazard. $\mathrm{com} /$ media/2390/lazards-levelized-cost-of-energy-analysis-90.pdf 
\$32-77. For comparison, the levelized cost of $1 \mathrm{MWh}$ of power generated by a combination cycle gas-driven turbine, coal power plant and nuclear power plant amounts to $\$ 52-78, \$ 65-150$ and $\$ 97-136$, respectively. So, generally, solar and wind energies are competitive though in some regions they may be more expensive than traditional power generation. In similar research by other agencies, somewhat different statistics is provided, however, the conclusions are generally the same. In addition to the above, unlike power generation on the basis of fossil fuel and nuclear generation RES technologies are expected to become less expensive. According to the IRENA ${ }^{1}$ latest report, by 2025 average costs related to solar and wind generated power will fall by $59 \%$ and $26-35 \%$, respectively.

In the past few years, it was repeatedly stated in research papers of numerous representatives of academic circles and analytical centers that successful development of RES and even a complete switchover of individual countries to those technologies was no longer a technical or economic problem, that is, at present everything depends entirely on political will and private companies' intentions to utilize RES.

It is to be noted that some cities, regions and even countries have already set an objective and even specific deadlines for a complete or partial switchover to RES. For example, San-Diego and San Francisco are planning to switch over to RES by 2035 and 2030, respectively, the US State of California will shift $50 \%$ of its power generation to RES by 2030 , while Denmark $-100 \%$ by 2035.

In the past few years, business has started to switch over voluntarily to RES. A few years ago, it was not expedient in economic terms. However, after RES technologies became substantially less costly transnational companies have started to introduce their own capacities or conclude relevant contracts with generating companies and RES-project developers. So, in 2014 a campaign RE100 - was launched for a complete switchover to RES before a certain deadline. The number of its participants includes over 70 transnational corporations such as Coca-Cola, Google, Goldman Sachs, Johnson\&Johnson and other. In May 2016, over 60 US transnational companies made the Alliance for Renewable Energy which is to facilitate large and small companies in shifting to RES utilization. By using renewable energy, companies expect to cut their costs on power: they choose competitive RES in their regions and conclude long-term fixed price agreements as prices on traditional energy are expected to go up.

According to the data of the Solar Energy Industries Association ${ }^{2}$, if in the US as early as 2010 coal power plants accounted for one-third of capacities put into operation, starting from 2014 they build no more such plants. While the share of solar power plants in the total number of new power generation projects amounted to about 30\% in 2013-2015 and rose to $64 \%$ in Q1 2016, wind plants accounted of late for about one-third of newly introduced capacities. According to Bloomberg ${ }^{3}$, in 2015 solar and wind energies ensured globally $50 \%$ of the entire volume of new installed generation capa-

1 IRENA. The Power to Change: Solar and Wind Cost Reduction Potential to 2025, 2016. http://www.irena.org/DocumentDownloads/Publications/IRENA_Power_to_Change_2016.pdf

2 SEIA. Solar Market Insight Report 2016 Q2, 2016. https://www.seia.org/research-resources/solar-market-insight-report-2016-q2

3 Bloomberg. Clean Energy Investment by the Numbers - End of Year 2015, 2015. http:// www.bloomberg.com/company/clean-energy-investment/ 
city in the power industry, including fossil fuel, nuclear energy and other RES. According to the data of IRENA ${ }^{1}$, in the renewable energy sector $8.1 \mathrm{~m}$ people were employed globally by early 2016. It is to be noted that in China there were more workers in the RES sector than in the oil and gas sector: $3.5 \mathrm{~m}$ and $2.6 \mathrm{~m}$ people, respectively.

In 2015 , wind energy generated $42.1 \%$ of all power consumed in Denmark. Some countries ensure sometimes their needs in power by means of RES alone. For example, in May 2016 Portugal's power industry operated for four days utilizing only solar, wind and water energy. In December 2015, in the state of Taxes wind energy ensured $40 \%$ of the state's need in power for 17 hours running. In Germany, during some short periods when there is excessive RES generation (sunny and windy days) negative prices on power are set.

In Russia, no radical changes on the power market are expected so far. Starting from 2013, state support has been rendered to the RES sector and some projects in that field are being carried out. However, in accordance with the officially approved plan only $6 \mathrm{GW}$ of new RES power plants ensuring $4.5 \%$ of the entire power consumption in the country will be built by 2024 . Competition among developers in the RES field is rather low. Production of domestic equipment for renewable energy is underdeveloped, while in plenty of segments of the RES sector it is virtually non-existent. However, in Russia there are reasons for restrained positive expectations.

In June 2016, it became known that in the period till 2020 Rosatom entities were going to invest over $\mathrm{Rb} 80 \mathrm{bn}$ in wind-driven generation in Russia and Rosatom was looking for a foreign partner to localize manufacturing of wind generators. In addition to the above, some experts believe that promotion of RES activities is possible in 2017 which is declared the year of ecology in accordance with the executive order of the President of the Russian Federation.

So, in years to come the existing trends are expected to consolidate in the power industry: prices on RES technologies are going to depreciate and the share of RES in the power sector is bound to rise. Prices on fossil fuel will either remain at the current level or appreciate. The above factors create favorable conditions for radical changes in the power industry. Most probably, Russia will follow global trends, but with some lag.

1 IRENA. Renewable Energy and Jobs: Annual Review, 2016. http://www.irena.org/ DocumentDownloads/Publications/IRENA_RE_Jobs_Annual_Review_2016.pdf 